\title{
Disharmonized the Regulation of Biological Resources and its Ecosystem in Indonesia
}

\author{
Sumurung P. Simaremare ${ }^{1, *}$ and Muhammad Dzikirullah H. Noho ${ }^{2}$ \\ ${ }^{1}$ Universitas Sumatera Utara, Medan, and Kejaksaan Republik Indonesia; University Street No.19, Padang \\ Bulan, Medan, 20155, Indonesia \\ ${ }^{2}$ Universitas Diponegoro, Semarang, and Lecturer Universitas Hasyim Asy'ari Tebuireng, Jombang, Irian \\ Jaya Street No.55, Cukir, Jombang Regency, 61471, Indonesia
}

\begin{abstract}
The goal of state control over natural resources is an anticipatory step to avoid the widest possible use by individuals or legal entities as a means of oppression and exploitation of others. However, in reality, many regulations overlap and are not in harmony with one another. The author of this study uses normative juridical research. The definition of normative juridical is a type of research that emphasizes more on library research, where the materials used will be obtained from laws, literature, mass media, which are related to writing materials. This study found that the arrangement of living natural resources in Indonesia that is less harmonious is: a. Law Number 21 of 2004 concerning Ratification of the Cartagena Protocol On Biosafety To The Convention On Biological Diversity and b. Constitutional Court Decision No.35/PUU-X/2012.
\end{abstract}

Keywords: Disharmonized, Regulation, Biological Natural Resources, Ecosystem, Indonesia.

\section{INTRODUCTION}

Formulation of Article 33 of the Constitution of 1945 not only guides the composition of the economy and the state's authority to regulate economic activities and natural resources contained therein but also reflects the ideals and beliefs that are firmly held and consistently fought for by the leaders of the nation to create social justice in the economic sector can achieve equitable prosperity, namely social justice for all Indonesian people (Wibowo, 2015). In other words, monopoly, oligopoly, or cartel practices in natural resource management are against the principles of Article 33 of the 1945 Constitution of the Republic of Indonesia (Max). State obligations as a manifestation of the relationship with the right to control the state with the greatest prosperity of the people can include (Mawuntu, 2012):

1. Only certain creates of efficiency (water and earth) and the results achieved (natural wealth) must significantly increase the community's prosperity and welfare.

2. Protect and guarantee all the people's rights in or on the earth, water, and certain natural resources that can be directly generated or enjoyed directly by the people.

*Address correspondence to this author at the Universitas Sumatera Utara, Medan, and Kejaksaan Republik Indonesia; University Street No.19, Padang Bulan, Medan, 20155, Indonesia; Tel: +620618213571;

E-mail: sumurungpsimaremare@gmail.com
3. Prevent all actions by any party that will cause the people to have no opportunity or lose their rights to enjoy natural resources.

As an embodiment of Article 33 of the 1945 Constitution of the Republic of Indonesia, a law was made to conserve living natural resources, namely Law Number 5 of 1990 concerning Conservation of Living Natural Resources and Their Ecosystems. As stated in the explanation, Law Number 5 of 1990 concerning the Conservation of Living Natural Resources and their Ecosystems is made based on several reasons, one of which is the living natural resources and their ecosystems, which are the most important part of natural resources which consist of animal, vegetable or in the form of natural resources. Natural phenomena, either individually or collectively, have functions and benefits as the constituent elements of the environment, whose presence cannot be replaced. Considering their irreplaceable nature and having an important position and role for human life, conservation of living natural resources and their ecosystems is an absolute obligation of each generation. Irresponsible actions that can cause damage to the nature reserve area and nature conservation area or actions that violate the provisions concerning the protection of protected flora and fauna are punishable by serious criminal penalties in the form of corporal punishment and fines. This serious punishment is deemed necessary because the damage or extinction of one element of the living natural resource and its ecosystem will result in a great loss to the community, which cannot be assessed materially. At the same

(C) 2021 Lifescience Globa 
time, its recovery to its original state is no longer possible.

The goal of state control over natural resources is an anticipatory step to avoid the widest possible use by individuals or legal entities as a means of oppression and exploitation of others. Besides, at the same time, to ensure that the use and utilization of all these potentials are truly intended for the people's greatest prosperity (Firmansyah, 2012).

However, in reality, many regulations overlap and are not in harmony with one another. This disharmony is disharmony, which is the opposite of harmonization. According to the online version of the Big Indonesian Dictionary, Harmony is harmony, searching for harmony. Ahmad M. Ramli, as quoted by Ani Purwadi, provides elements of the meaning of harmonization, among others (Purwadi, 2013):

1. The existence of things that are contradictory, anomalies;

2. Aligning contradictory matters proportionately to form a system;

3. A process or an effort to realize harmony, conformity, harmony, suitability, and balance;

4. Cooperation between various factors is such that they produce a sublime unity.

Furthermore, what is called legal harmonization is a process that harmonizes the rules of law both within the federal framework (which exists in the presence of superior regulatory entities to joint entities) through the adoption of regulatory models agreed upon at the multilateral level (such as a convention adopted in the OECD or UN) or through the unilateral adoption of a foreign sovereign legal system by a different sovereign state (Baffi \& Santella, 2011). Meanwhile, David Leebron, as quoted by Giandomenico Majone, claims that harmonization is a normative statement that differences in law and policy of two, or more, jurisdictions must be reduced: either by assigning decisions to the same political authority; or by different countries adopting similar laws and policies, even in the absence of such common authority (Majone).

As for several studies with similar titles that have been previously researched, including:

1. Samedi (2015) explains that biodiversity conservation aims to protect and utilize biological resources at the ecosystem, species, and genetic levels so that the legal framework for biodiversity conservation also needs to follow this diversity level. The KSDAHE Law needs to undergo significant material revisions and be in harmony with several other laws related to conservation, such as laws regarding the environment, spatial planning, fisheries, and laws regarding coastal and small islands implementation in the field can be useful.

2. Asram A.T.Jadda (2019), in his research, explained that Law Number 32 of 2009 concerning Environmental Protection and Management has projected Indonesia's biodiversity, but has not been optimal and comprehensive. This law is sufficient to be used to protect the existence of biological resources or biodiversity. There must be a law that provides more of its protection; if necessary, a sui generis should provide optimal protection by involving stakeholders and the stakeholders themselves.

3. Sudaryat (2020), in his research, explained that Indonesia, at the international level, had ratified the Convention on Biological Diversity, the Cartagena Protocol, and the Nagoya protocol. National laws and regulations such as the Law on Conservation of Living Natural Resources and their Ecosystems, the Forestry Law, and laws on intellectual property such as the Patent Law and the Protection of Plant Varieties have alluded to the protection of genetic resources in Indonesia. However, there are no specific laws and regulations (sui generis) which regulate genetic resources. The database on Indonesia's genetic resources is still limited as a means of non-legal protection. For this reason, it is necessary to optimize information technology in increasing genetic resource databases, and efforts to prevent claims from other countries, primarily since 2017, $50 \%$ of Indonesia's population has used information technology such as the internet. In 2019 it was targeted that all parts of Indonesia are connected via the internet network.

4. Rahayu, Susanto, \& Muliya (2018) in their research explain that in Ciomas village, the indigenous people in managing their natural resources in their ulayat lands have limited their land by name, for example, Leuweung Larangan, an area that cannot be changed from its original 
state. Its allotment is to fulfil spiritual needs or balance aspects of birth. Leuweung Larangan is a deposit area, a mandate from God and the ancestors to maintain its integrity. It cannot be contested and must be defended from all efforts and threats from outside parties.

Based on the four similar studies above, it can be seen that these studies have similarities and differences. The similarity with the research being studied is that all of them discuss biological natural resources and their ecosystems in Indonesia, emphasising aspects of existing regulations that can provide certainty and justice for the community. Meanwhile, the difference between the four studies above and the research being studied focuses on testing the disharmonized of regulations on living natural resources and their ecosystems in Indonesia, both from Law Number 21 of 2004 with the Constitutional Court Decision.

\section{LITERATUR REVIEW}

The basic term of the state among experts provides a variety of meanings. Aristotle defines that the state is a community power (association of families and villages) to achieve humanity's highest good. Meanwhile, Mac. Ivar tries to formulate the state as an association that organizes order in a society in an area based on a legal system run by a government to provide coercive power (Usman, 2015). As an agency, the state has the authority to control the natural resources that constitute the state's territory.

The word mastery in the online version of the Big Indonesian Dictionary has the meaning: 1) process, method, the act of controlling or empowering: 2) understanding or ability to use (knowledge, intelligence, etc.). Meanwhile, according to Kusbianto, tenure about land essentially has two meanings, namely juridically meaning that it refers to the existence of a legal relationship between a subject and a particular land. Meanwhile, in the usual sense, it is called a right, which contains certain authorities and obligations about the land being held (Kusbianto, 2010).

As explained in the background, the Indonesstate has the authority to control the earth, water, and natural resources contained therein by Article 33 paragraph (3) of the 1945 Constitution of the Republic of Indonesia. The phrase "controlled by the state" in Article 33 paragraph (3) of the 1945 Constitution according to Soepomo as one of the drafters of the 1945
Constitution which gives the following definition of "controlled" with the meaning of regulating and/or implementing especially to improve and consider production. Meanwhile, Bagir Manan provides the following definition of state control (Redi, 2015):

1. Control is a kind of ownership by the state, which means that the state through the Government is the sole authority to determine the right of authority over it, including here the earth, water, and the wealth contained therein;

2. Regulation and supervision of use and use;

3. Quality management plan and then in the form of state-owned corporations for only certain corporations.

In line with this, the Financial and Economic Committee formed by BPUPKI, chaired by Mohammad Hatta, formulated the following definition of being controlled by the state (Arizona, 2011):

1. The government must be a supervisor and regulator guided by the safety of the people;

2. The larger the company and the greater the number of people who depend on their livelihoods because the greater the government's participation;

3. The land must be under state control; and

4. Large mining companies are run as state enterprises.

Tenure rights or ownership rights that previously highlighted the authority's character to exclude other parties from controlled resources are no longer entirely valid because certain limitations accompany them. Even Yannacone, as quoted by Barnes, calls "social property", namely "property which has become vested with the public interest to such an extent that the property itself can be considered dedicated to public use." Besides, Karp explains tenure rights or ownership rights cannot be separated from the "duty of stewarship" which obliges the holder of tenure rights to use and manage the resources they own in a way that does not violate any significant values contained in these natural resources (Widowati, Yurista, \& Bosko, 2019).

Although controlled by the State, the State must attach importance to the prosperity of the people. The 
definition of people's prosperity in Article 33 paragraph (3) of the 1945 Constitution of the Republic of Indonesia shows that people must receive benefits and results from Indonesia's natural resources. In short, the State can regulate and use natural resources while still providing benefits and prosperity to Indonesia's people (Jazuli, 2015).

By the recommendation of the Supreme Court Case Number 001-21- 22 / PUU-I / 2003 and Case Number 3 / PUUVIII / 2010, there are 4 (four) benchmarks for achieving the prosperity of the people, namely (Sulaiman, Adli, \& Mansur, 2019):

1. There are benefits of natural resources for the people;

2. The level of participation in the benefits of natural resources for the people;

3. The level of people's participation in determining natural resources;

4. Respect for the rights of the people from generation to generation in utilizing natural resources.

State control of natural resources in Indonesia to create people's prosperity can be done through the conservation of living natural resources itself. In general, conservation means preservation, namely preserving/preserving the carrying capacity, quality, function, and capability of the environment in a balanced manner which has the following objectives (Rachman, 2012):

1. Realizing the preservation of living natural resources and the balance of their ecosystems so that they can further support efforts to improve the welfare and quality of human life;

2. To conserve the ability and utilization of living natural resources and their ecosystems in harmony and balance;

3. One of the efforts to maintain animal preservation is that without conservation, it will damage the animals' natural habitat.

The management of biodiversity in Indonesia is legally protected according to the relevant laws. There are about ten material laws related to biodiversity management in Indonesia, including (Mahipal, 2018):

1. Law of the Republic of Indonesia Number 5 of 1990 concerning Conservation of Living Natural Resources and their Ecosystems;
2. Law No. 5/1994 concerning Ratification of the United Nations Convention on Biological Diversity (United Nations Convention on Biological Diversity);

3. Law of the Republic of Indonesia Number 32 the Year 2009 concerning Environmental Protection and Management;

4. Law of the Republic of Indonesia Number 4 of 2006 concerning Ratification of the International Treaty on Plant Genetic Resources for Food and Agriculture (Agreement on Plant Genetic Resources for Food and Agriculture);

5. Law of the Republic of Indonesia Number 12 of 1992 concerning Plant Cultivation System;

6. Law of the Republic of Indonesia Number 26 of 2007 concerning Spatial Planning;

7. Law of the Republic of Indonesia Number 27 of 2007 concerning Management of Coastal Areas and Small Islands;

8. Law of the Republic of Indonesia Number 31 of 2004 concerning Fisheries in conjunction with Law of the Republic of Indonesia Number 45 of 2009 concerning Amendments to Law No.31 of 2004 concerning Fisheries;

9. Law of the Republic of Indonesia Number 32 of 2004 concerning Regional Government as amended into Law Number 23 of 2014 as replaced by Government Regulation instead of Law Number 2 of 2015 and replaced again by Law Number 9 of 2015 concerning Second Amendment to Law -Law Number 23 of 2014 concerning Regional Government; and

10. Law of the Republic of Indonesia Number 41 of 1999 concerning Forestry.

In Indonesia, conservation policies are beginning to experience a paradigm shift, from initially having the principle of conservation to conservation itself to conservation, which has a socio-economic function beneficial to local communities. Conservation is not human with the surrounding nature. Collaboration and real partnerships that hold responsible parties and have their respective rights and obligations are some of the keys to successful conservation with a biocultural approach. Various anthropological studies indicate that areas with high biodiversity levels are usually inhabited 
by traditional indigenous peoples, especially in Latin America, Africa, and Southeast Asia. Even the Amazon jungle - a region known for its natural purity - is home to hundreds of indigenous groups. They have become a facilitator for their natural surroundings from creating to generations (Fajrini, 2015).

This interdiction task provides them with their rights and obligations towards the environment. Communities that have historically interacted with the environment and are the most directly affected parties are essential stakeholders in making decisions related to conservation. Biodiversity conservation should also consider the diversity of the surrounding cultures. Conservation policies that cut the cultural relationship between the community and nature will receive high resistance and impact the achievement of conservation goals itself. Appreciation for this cultural relationship gives birth to the community's biocultural rights to support their environment (Fajrini, 2015).

\section{METHODS}

The whole study includes a positivist sort of legal research. The definition of normative juridical is a type of research that emphasizes more on library research, where the materials used will be obtained from laws, literature, mass media, which are related to writing materials. Besides the data obtained from the literature, the author will also describe the results of this study. After obtaining the data using normative juridical, then the writer describes in words in the research entitled Disharmony of Regulation of Biological Resources and Their Ecosystems in Indonesia (Riyanto, 2016).

The approach method used is the statutory, historical, and conceptual approach. The researcher will collect and describe the various regulations that exist in living natural resources and their existing ecosystems today through the statutory approach. Meanwhile, the conceptual approach will explain the concepts of living natural resources in Indonesia. Through a statutory approach, researchers will collect and present various regulations. The analytical method used refers to the 1945 constitution of the Republic of Indonesia as the Indonesian constitution, existing regulations, looking at existing legal principles and concepts of living natural resources, describing the regulation of living natural resources in other countries, and then exploring disharmony among existing regulations. Normative juridical research is needed because it is necessary to make an inventory of positive law, the discovery of the principles and basic philosophy (dogma or doctrine) of positive law; and inconcreto legal findings that are feasible to be applied to resolve a particular legal case (Noho, 2019).

\section{RESULTS AND DISCUSSION}

Since stated in Section 1 of Law No. 5 of 1990 on the conservation of living natural resources and their ecosystems, living natural resources are biological elements in nature consisting of vegetable natural resources (plants) and animal natural resources. (animals) together with the surrounding non-living elements as a whole form an ecosystem. Apart from that, the law also describes the conservation and ecosystem of living natural resources. Conservation of living natural resources is the management of living natural resources whose utilization is carried out wisely to ensure their supply's sustainability while maintaining and increasing the quality of their diversity and value. Meanwhile, the ecosystem of living natural resources is a system of reciprocal relationships between elements in nature, both living and non-living, which are interdependent and influence each other.

The success of the conservation of living natural resources and their ecosystems is closely related to the achievement of three conservation targets, namely:

1. To ensure the maintenance of ecological processes that support a life support system for the continuity of development and human welfare (protection of life support systems);

2. Ensuring the maintenance of the diversity of genetic sources and types of ecosystems so that they can support development, science, and technology that enables the fulfillment of human needs who use living natural resources for welfare (preservation of germplasm sources);

3. Controlling how living natural resources are used so that their sustainability is guaranteed. As a side effect of science and technology that is not wise, the use and allocation of land have not been harmonious, and that the target of conservation is not optimal, both on land and in the waters can cause symptoms of genetic erosion, pollution, and a decrease in the potential of living natural resources (sustainable use).

To achieve prosperity for the Indonesian people over control of natural resources, regulations regarding living natural resources must be interrelated and 
harmonious. However, regulations regarding living natural resources are still not in harmony with one another. As quoted by Wasis Susetio, L.M. Gandhi said that disharmony in Indonesia arises due to 8 (eight) factors, namely (Susetio, 2013):

1. There are many over a few other variations among rules and regulations. This increasing number of rules makes it difficult to know or about all of them. Therefore, the provision which states that all people are deemed to be aware of all applicable laws is an absolute necessity;

2. The controversy between law and implementing regulations;

3. Differences between statutory regulations and government agency policies. Usually, the technical guidelines often conflict with the legislation to be implemented;

4. Differences between statutory regulations and jurisprudence and circular letters of the Supreme Court;

5. Conflicting Central agency policies;

6. Differences between Central and Regional Government policies;

7. Differences between legal provisions and the formulation of certain definitions;

8. The conflict between powers of government agencies due to unclear and unclear division of authority.

According to researchers, some arrangements for living natural resources in Indonesia that are less harmonious are as follows:

\section{Law No. 21 of such 2004 on the ratification of the Cartagena Procedure on Biosafety to the Convention on Biological Diversity (Cartagena Protocol Concerning Biological Security Over Conventions On Biological Diversity)}

The Protocol on Biosafety of Cartagena (The Guidelines on Biosafety of the Biological diversity) is an international agreement regulating transboundary movement, handling, and use of living modified organisms (LMOs), which is one of the products law that emphasizes the need for a precautionary approach. The purpose of the Cartagena Protocol can be seen in Article 1, namely:
In keeping with the precautionary approach in Principle 15 of the Rio Declaration on Environment and Development, the Protocol's objective is to ensure an adequate level of protection in the area of the safe transfer, handling, and use of living modified organisms. Generated from modern biotechnology that may have adverse effects on the conservation and sustainable use of biodiversity, taking into account the risks to human health and focusing on movement across borders.

Article 1 of the Cartagena Protocol emphasizes that the entire agenda of adopting the protocol is to protect and conserve biodiversity based on a precautionary approach. Although the main questions regarding what can be categorized as a hazard or a hazard remain, a regulatory framework is still needed because an understanding of hazards and hazards and the value of biodiversity must be based on a biological and ethical context (Santoso, Sunarto, Martono, \& Supriyono, 2017). Indonesia, which has ratified this protocol, automatically becomes the party, which will benefit from the objectives of the establishment of this international agreement, namely the conservation of biodiversity, the sustainable use of its components, and sharing the benefits resulting from the utilization of genetic resources fairly and equitably, including through adequate access to genetic resources and by transferring appropriate technology, and by taking into account all rights to these resources and technology, as well as with adequate funding (Indrayati \& Triatmodjo, 2017).

Meanwhile, Law Number 5 of 1990 concerning Conservation of Living Natural Resources and their Ecosystems as referred to in Article 3 provides the following objectives: Conservation of living natural resources and their ecosystems aims to achieve the preservation of living natural resources and the balance of their ecosystems so that they can further support efforts to improve community welfare and the quality of human life.

Much of agricultural and livestock production is the result of genetic modification as science advances. Besides, Article 5 of Law Number 5, the Year 1990 concerning Conservation of Living Natural Resources and their Ecosystems also does not explicitly describe the scope of the regulation of safe genetic modification of modern biotechnology. Whereas Article 4 of the 
Cartagena Protocol regarding genetic modification of modern biotechnology, which reads, "This protocol applies to the transboundary movement, transit, handling and use of all living modified organisms that may hurt the conservation and sustainable use of biological diversity, with also consider the risks to human health."

This other problem that's not regulated by Law 5 of 1990 concerning Conservation of Living Natural Resources and their Ecosystems, namely the mandate of Article 10 which regulates that the importing party is obliged to notify in writing or after 90 days without written approval, then after 270 days of receipt of notification the importer notifies in writing to the notification provider and the biosafety clearinghouse to approve or prohibit imports or request additional information or to extend the time required to avoid or minimize potential losses to the conservation of biodiversity and human health (Simarmata, 2018), the provisions of Article 15, and the provisions of Article 16 which states:

Article 15:

a. Risk assessments carried out by this Protocol shall be carried out scientifically, by Annex III, and taking into account recognized risk assessment techniques. Such risk assessment shall be based, as a minimum, on the information provided by Article 8 and other available scientific evidence to identify and evaluate the possible adverse effects of living modified organisms on the conservation and sustainable use of biological diversity, also taking into account the risks to human health;

b. The importing party must ensure that a risk assessment is carried out for decisions made under Article 10. This may require the exporter to carry out a risk assessment;

c. The notifier will bear the risk assessment cost if the importing Party so requires it.

Article 16:

a. The Parties shall establish and maintain appropriate mechanisms, taking into account Article $8 \mathrm{(g})$ of the Convention; actions and strategies for regulating, managing, and controlling the risks identified in the risk assessment provisions of this Protocol relating to the use, treatment, and movement across borders genetically modified organisms. b. Measures based on risk assessment shall be implemented to the extent necessary to prevent the adverse effects of living modified organisms on the conservation and sustainable use of biological diversity, also taking into account risks to human health, within the territory of the Party of import.

c. Each Party shall take appropriate steps to prevent the accidental transboundary movement of living modified organisms, including steps requiring that a risk assessment be carried out before the first release of the Live a various schemes.

d. Without prejudice to the paragraph's provisions above, each Party shall seek to ensure that any alive various schemes, whether imported or locally developed, have undergone a period of observation appropriate to its life cycle or time of manufacture before inclusion in its purpose use.

e. The Parties collaborates closely with a view to:

1. Classifying trying to live modified crops or even just the particular issues of microorganisms that could have negative impacts also on sustainability and integrated nature, considering adverse effects on human health;

2. Take appropriate steps about the treatment of living modified organisms or certain traits.

\section{The Decision of the Constitutional Court of the Republic of Indonesia No. 35 / PUU-X/2012}

On May 16, 2013, issued decision number 35 / PUU-X / 2012 regarding the application for constitutionality review of Law Number 41 of 1999 concerning Forestry. In this decision, the Constitutional Court stated that customary forest is a forest within the territory of customary law communities and state forests as referred to in the Forestry Law, excluding customary forests and that "... the state only has indirect authority over customary forests". Based on this decision, the customary forest is included in the private forest category, not state forest (Yulyandini, 2018). Previously, in Law Number 41 of 1999 concerning Forestry, customary forests were considered part of state forests. Law Number 41 of 1999 concerning Forestry, especially Article 67 and its explanation, acknowledges the existence of customary law communities if they meet elements such as (Salamat, 2015): 
1. The community is still in the form of a community,

2. There are institutions in the form of customary rulers,

3. There is a clear customary law area,

4. There are legal institutions and instruments, especially customary courts, which are still adhered to and still collect forest products in the surrounding forest area to fulfill their daily needs.

Disharmony between Law Number 5 of 1990 concerning Conservation of Living Natural Resources and Their Ecosystems and the Decision of the Indonesian Constitutional Court No. 35 / PUU-X / 2012 can be seen from the inability to implement Article 12 which in terms of preservation of plant and animal diversity and their ecosystems, is carried out by maintaining the integrity of the nature reserve area so that it remains in its original state. The recognition of customary forests as private forests that can be managed by the Customary Law Community can enable the forest to not be in its original state. Besides, with the Constitutional Court Decision No. 35 / PUU-X / 2012, biosphere reserve areas established by the government can also be partially or completely transferred from the state to the MHA for its management and utilization. This transition's rights have been recognized and respected, including the right to customary forest, which is essentially the forest of the rights of indigenous peoples in the Decision of the Indonesian Constitutional Court No. 35 / PUU-X / 2012 (Simarmata, 2018). Thus, there is no harmonization between Law Number 5 of 1990 concerning Conservation of Living Natural Resources and Their Ecosystems and the Decision of the Indonesian Constitutional Court No. 35 / PUU-X / 2012 will confuse the management and use of the biosphere reserve

\section{CONCLUSIONS}

Based on the article written about "Disharmony of Regulation of Living Natural Resources and Their Ecosystems in Indonesia" it can be concluded that: The State must prioritize prosperity for the people even though the State controls it. The definition of people's prosperity in Article 33 paragraph (3) of the 1945 Constitution of the Republic of Indonesia shows that people must receive benefits and results from Indonesia's natural resources. State control of natural resources in Indonesia to create people's prosperity can be done by conserving living natural resources itself. The arrangement of living natural resources in Indonesia that is less harmonious is a. Law Number 21 of 2004 concerning Ratification of the Cartagena Protocol On Biosafety To The Convention On Biological Diversity and b. Constitutional Court Decision No. 35 / PUU-X / 2012.

\section{REFERENCES}

A.T.Jadda, A. (2019). Tinjauan Hukum Lingkungan Terhadap Perlindungan Dan Pengelolaan Keanekaragaman Hayati. Madani Legal Review, 3 (1), 39-62. https://doi.org/10.31850/malrev.v3i1.344

Arizona, Y. (2011). Development of the Constitutionality of State Control over Natural Resources in the Decision of the Constitutional Court. Journal of the Constitution 8 (3), 260.

Baffi, E., \& Santella, P. (2011). The Economics Of Legal Harmonization. Encyclopedia Of Law And Economics 7, 3. https://doi.org/10.2139/ssrn.1690967

Fajrini, R. (2015). Hak Biokultural Masyarakat Dalam Kebijakan Konservasi Sumber Daya Hayati. Jurnal Hukum Lingkungan, 2 (2), 101-103.

Firmansyah, A. (2012). Interpretation of Article 33 of the 1945 Constitution in Building the Economy in Indonesia. Journal of Law Syiar Hukum 13 (1), 283.

Indrayati, Y., \& Triatmodjo, M. (2017). Benefits for Indonesia as a Party to the Convention on Biological Diversity and the Nagoya Protocol in Protecting Genetic Resources and Traditional Knowledge. Journal of Environmental Law Development 2 (1), 74 https://doi.org/10.24970/jbhl.v2n1.7

Jazuli, A. (2015). Dynamics of Environmental Law and Natural Resources in the Framework of Sustainable Development. Rechtvinding Journal 4 (2), 183.

Kusbianto. (2010). Conflict on Plantation. Medan : USU Press.

Mahipal. (2018). Kebijakan Pengelolaan KeanekaragamanHayati. Jurnal Pendidikan Insan Kamil Al Ihya, 1 (1), 23-24.

Majone, G. (n.d.). Policy Harmonization: Limits and Alternatives. Journal of Comparative Policy Analysis: Research and Practice 16 (1), 4. https://doi.org/10.1080/13876988.2013.873191

Mawuntu, J. R. (2012). The Concept of State Control Based on Article 33 of the 1945 Constitution and the Decision of the Constitutional Court. Unsrat Law Journal 20 (3), 16.

Max, B. S. Legal Dogmatic Approaches and Legal Theory to the Social Function of Property Rights in the Context of the State of Law of Pancasila. Jakarta: Atma Jaya Catholic University of Indonesia.

Noho, M. D. (2019). Politik Hukum Pengaturan Build Operate Transfer (BOT) Di Indonesia: Di Masa Lalu, Saat Ini, Dan Akan Datang. Jurnal Hukum Media Bhakti, 3 (1), 90. https://doi.org/10.32501/jhmb.v3i1.51

Purwadi, A. (2013). Harmonization of Development Planning Arrangements between Central and Regions in the Era of Regional Autonomy. Perspective Journal 18 (2), 93-94.

Rachman, M. (2012). Conservation of Values and Cultural Heritage. Indonesian Journal of Conservation 1 (1), 31.

Rahayu, M. I., Susanto, A. F., \& Muliya, L. S. (2018). Hak Mayarakat Adat Dalam Pengelolaan Sumber Daya Alam (Suatu Studi Pengelolaan Sumber Daya Alam Oleh Masyarakat Adat Desa Ciomas). Journal of Indonesian Adat Law, 2 (3), 1-22. https://doi.org/10.46816/jial.v2i3.5 
Redi, A. (2015). Dynamics of Conceptions of State Ownership of Natural Resources. Journal of the Constitution 12 (2), 406407.

Riyanto, A. (2016). The Existence and Legal Position of the Chief of Police Circular Regarding the Handling of Hate Speech. Journal of the Light of Justice 3(2), 3.

Salamat, Y. (2015). Post-Decision Analysis of the Constitutional Court Number 35 / Puu-X / 2012 on the Drafting of Regional Regulations based on Article 67 Paragraph (2) of Law Number 41 Year 1999 concerning Forestry. Indonesian Legislation Journal 12 (1), 3.

Samedi. (2015). Konservasi Keanekaragaman Hayati di Indonesia: Rekomendasi Perbaikan Undang-Undang Konservasi. JurnalL Hukum Lingkungan, 2 (2), 2-28. https://doi.org/10.38011/jhli.v2i2.23

Santoso, W. Y., Sunarto, Martono, E., \& Supriyono, H. (2017). Significance of the Precautionary Approach in Regulating Transgenic Organisms in Indonesia. Journal of Environmental Law 4 (1), 104-105. https://doi.org/10.38011/jhli.v4i1.51

Simarmata, J. (2018). Overlapping Laws on the Conservation of Living Natural Resources and Their Ecosystems. Indonesian Legislation Journal 15 (3), 186-193.
Sudaryat. (2020). Perlindungan Hukum Sumber Daya Genetik Indonesia Dan Optimalisasi Teknologi Informasi. Bina Hukum Lingkungan, 4 (2), 236-250. https://doi.org/10.24970/bhl.v4i2.98

Sulaiman, Adli, M., \& Mansur, T. M. (2019). Legal Irregularities in the Recognition and Protection of Customary Law in Indonesia, Journal of Law Reform 15 (1), 17. https://doi.org/10.14710/Ir.v15i1.23352

Susetio, W. (2013). Disharmony of Legislative Regulations in the Agrarian Sector. Lex Jurnalica 10 (3), 136.

Usman. (2015). The State and Its Functions (Study of Political Thought). Al-Daulah Journal 4 (1), 132-133.

Wibowo, S. E. (2015). Understand the meaning of Article 33 of the 1945 Constitution of the Republic of Indonesia regarding Control by the State of Natural Resources. Indonesian Legislation Journal 12 (4), 2.

Widowati, D. A., Yurista, A. P., \& Bosko, R. E. (2019). Ownership Rights Over Natural Resources in Conception and Elaboration in the Prevailing Laws. Indonesian Legislation Journal 16 (2), 152.

Yulyandini, M. D. (2018). The State's Indirect Authority Against Customary Forests Post Constitutional Court Decision Number 35 / PUU-X / 2012. Jurnal Jurist-Diction 1 (1), 244. https://doi.org/10.20473/jd.v1i1.9744

(C) 2021 Simaremare and Noho; Licensee Lifescience Global.

This is an open access article licensed under the terms of the Creative Commons Attribution Non-Commercial License (http://creativecommons.org/licenses/by-nc/3.0/) which permits unrestricted, non-commercial use, distribution and reproduction in any medium, provided the work is properly cited. 